\title{
Ultrastructural Variations of Antennae and Labia Are Associated with Feeding Habit Shifts in Stink Bugs (Heteroptera: Pentatomidae)
}

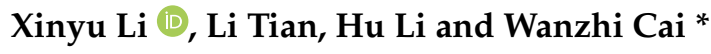

check for updates

Citation: Li, X.; Tian, L.; Li, H.; Cai, W. Ultrastructural Variations of Antennae and Labia Are Associated with Feeding Habit Shifts in Stink Bugs (Heteroptera: Pentatomidae). Biology 2021, 10, 1161. https:// doi.org/10.3390/biology10111161

Academic Editor: Klaus H. Hoffmann

Received: 10 October 2021

Accepted: 5 November 2021

Published: 10 November 2021

Publisher's Note: MDPI stays neutral with regard to jurisdictional claims in published maps and institutional affiliations.

Copyright: (c) 2021 by the authors. Licensee MDPI, Basel, Switzerland. This article is an open access article distributed under the terms and conditions of the Creative Commons Attribution (CC BY) license (https:/ / creativecommons.org/licenses/by/ $4.0 /)$.
Department of Entomology and MOA Key Lab of Pest Monitoring and Green Management, College of Plant Protection, China Agricultural University, Beijing 100193, China; lixinyu91@cau.edu.cn (X.L.); ltian@cau.edu.cn (L.T.); lih@cau.edu.cn (H.L.)

* Correspondence: caiwz@cau.edu.cn

Simple Summary: Stink bugs (Pentatomidae) are one of the most diverse insect groups in suborder Heteroptera (Hemiptera). They are either plant feeders or predators, comprising series of invasive agricultural pests and natural enemies with great economic importance. Species of stink bugs possess various antennal and mouthpart traits apparently related with feeding habits, but key morphological traits associated with feeding habit shift remain largely unexploited. In this study, we compare the ultrastructures of antennae, labia, and mandibular and maxillary stylets of 17 pentatomid species, representing both phytophagous and predatory species chosen from four subfamilies. We identify a set of key ultrastructural characteristics closely associated with feeding habit transition in stink bugs and discuss their adaptative implications in an evolutionary aspect.

Abstract: The family Pentatomidae (stink bugs) is one of the largest groups in Heteroptera, containing many important pests and natural enemies. They exhibit highly diversified feeding habits and related structural modifications, but the key morphological characteristics associated with feeding habit radiation remain unclear. In the current study, we address this question by analyzing morphological variations of feeding related organs. We compare the ultrastructures of antennae and mouthparts across the chosen 17 species in Pentatomidae, representing both plant feeders and predators from four subfamilies. A strong association between ultrastructural adaptation and feeding habit transition has been revealed. The long, sharp, and hook-like mandibular teeth and maxillary barbs are exclusively present in predatory Pentatomidae, suggesting their tight association with the shift of feeding habit from phytophagy to predation. Significant differences between phytophagous and predatory species are also found in antennal and labial sensilla types and arrangements, implying their important function in food selection. Our data identify a series of key morphological structures associated with feeding habit variations among stink bugs, which will facilitate future studies on adaptive evolution of feeding habits, utilization, and population control of economic species in Pentatomidae as well as in other heteropteran lineages.

Keywords: Pentatomidae; mouthpart; antenna; morphology; ultrastructure; adaptation

\section{Introduction}

Heteroptera (commonly known as true bugs) are the largest group with great morphological and biological diversifications in Hemiptera. They are distributed worldwide, inhabiting various natural and agricultural habitats (e.g., terrestrial and aquatic; shrublands, forests, and farmlands) and exhibiting significantly diversified feeding habits [1-3]. Adaptations in feeding-associated morphology have been shown among true bugs with distinct food preferences [4-7]. For instance, predatory heteropterans tend to have stout and strong labium, enclosing highly serrated maxillae fringed with sharp teeth $[4,5,8]$, whereas herbivorous lineages often have slim and slender labia, possessing smooth-edged 
maxillae $[4,9,10]$. Substantial modifications of antennae have been documented to be related to variations in feeding habits, displaying a large number of mechanoreceptors in plant feeders [11], and specific types of antennal sensilla existed predominantly in predators [12]. Consequently, it is hypothesized that the evolutionary radiation of true bugs has been partially driven by a shift in feeding habit and a modification of feeding-associated morphology $[2,4,13,14]$. However, a lack of comparative analysis of the key morphological adaptations in the context of phylogeny is an obstacle to further our understanding of heteropteran evolution [15].

Pentatomidae Leach is one of a few heteropteran families containing both plant feeders and predators and hence is a good example for characterizing key morphological changes along with feeding habit transition [16]. Despite most Pentatomidae being phytophagous insects feeding on a wide range of plants, the subfamily Asopinae Amyot \& Serville are generalist predators, preying on a large variety of arthropods $[3,17]$. Diversified feeding habits not only contribute to a broad ecological adaptation of stink bugs but also tied them closely with agriculture and forestry. Some plant feeding species are important invasive and agricultural pests worldwide, e.g., Halyomorpha halys (Stål, 1855) [18], damaging numerous crops and fruits due to direct feeding or transmission of plant pathogens [19-23], while some predatory species, e.g., Eocanthecona furcellata (Wolff, 1811) [24], have become promising biological control agents against lepidopteran and coleopteran pests $[17,25]$. As a result, many pentatomid species have received considerable attention due to their great economic importance ([26] and pp. 681-756 in [3]). Nonetheless, we have limited knowledge about key morphological traits associated with feeding habit variation in this group. By far, ultrastructures of feeding related organs in pentatomids have only been described in a few polyphagous species in Pentatominae Leach and Asopinae [27-30]. Other subfamilies, especially those representing oligophagous feeding pattern, are still largely unexplored. Such limited and biased taxa sampling impedes our understanding on how morphological evolution is associated with feeding habits transition in this insect group.

In the present study, we compared the ultrastructures of the mouthparts and antennae of 17 species from 4 subfamilies in Pentatomidae, representing phytophagous (oligophagy and polyphagy) and predatory (polyphagy) feeding habits, and discussed key morphological modifications associated with the variation of feeding habits in the aspect of phylogeny.

\section{Materials and Methods}

\subsection{Taxon Sampling}

A total of 17 pentatomid species, representing plant feeders and predators from 4 subfamilies, Asopinae, Pentatominae, Phyllocephalinae and Podopinae, were included in a comparative morphological and phylogenetic analysis (Table S1). The sample comprises 6 species characterized in the present study, namely Cressona divaricata Zheng \& Zou, 1982 [31]—Phyllocephalinae Amyot \& Serville; Eo. furcellata—Asopinae; Eurydema dominulus (Scopoli, 1763) [32]; H. halys, Plautia crossota (Dallas, 1851) [33]-Pentatominae; and Scotinophara lurida (Burmeister, 1834) [34]—Podopinae Amyot \& Serville, and another 11 species with their relevant ultrastructures documented previously (Table S1). Adult specimens examined in this study were collected from several localities in China in 2012-2020 (Table S2) and preserved in 95\% ethanol. Three males and three females of each species were prepared for morphological examination except that a male and a female of C. divaricata were examined due to the small amount of available specimens. Host plant information of the sampled pentatomid species was summarized from publications and is provided in Table S3.

\subsection{Sample Preparation for Scanning Electronic Microscopy}

Antennae, labia, and stylet bundles of the examined specimens were removed from the heads, immersed in PBS buffer $(\mathrm{pH}=7.4)$, and cleaned in an ultrasonic cleaner $\left(30^{\circ} \mathrm{C}\right.$, $30 \mathrm{~s})$. The samples were then dehydrated through an ascending series of ethanol $(70 \%, 80 \%$, 
$85 \%, 90 \%, 95 \%$, and $100 \%$ ethanol, $15 \mathrm{~min}$ in each), followed by drying in $\mathrm{CO}_{2}$ using a Leica EM CPD300 critical point dryer. The prepared samples were then mounted on aluminum stubs using double-side carbon adhesive tape, coated with platinum, and examined using a HITACHI SU8010 scanning electronic microscope at the Institute of Microbiology, Chinese Academy of Sciences (Beijing, China). The length, basal diameter, and distribution of antennal and labial sensilla are provided in Tables S4-S9, and the average density of sensilla basiconica on antennal distiflagellomere are provided in Table S10. The morphological terminology follows Schuh and Weirauch [2], Cobben [4], and Schneider [35].

\subsection{DNA Extraction, Molecular Marker Amplification, and Sequencing}

Fragments of two mitochondrial genes, $\operatorname{cox} 1$ and $r r n L$, were used as genetic markers for phylogenetic analysis. Sequences of these two genes of $C$. divaricata were sequenced in the present study, and that of 16 species (except for C. divaricata) were retrieved from GenBank (Table S1). The total genomic DNA of $C$. divaricata was extracted from thoracic muscle tissues from an adult specimen using the TIANamp Genomic DNA Kit (TIANGEN, Beijing, China). The remaining body parts were retained as vouchers and deposited in China Agricultural University. Mitochondrial fragments were amplified using the universal insect mitochondrial primers C1-J1709 (5'-AATTGGWGGWTTYGGAAAYTG-3'), C1-N2776 (5' GGTAATCAGAGTATCGWCGNGG-3'), LR-J12888 (5'-CCGGTCTGAACTCAGATCATGTA $\left.-3^{\prime}\right)$, and LR-N13889 (5'-ATTTATTGTACCTTTTGTATCAG-3') [36]. The PCR reactions and amplification conditions were conducted following Li et al. [37]. Purification and sequencing of PCR products were performed by Tsingke Biotechnology Co., Ltd., Beijing, China. The sequences were assembled using SeqMan Pro v. 7.1.0 (DNASTAR Inc., Maddison, WI, USA), aligned by MAFFT v. 7 online service [38,39] with default parameters, and deposited in GenBank with the accession numbers MZ673416 and MZ676042 (Table S1).

\subsection{Phylogenetic Analysis}

The phylogenetic relationships of all 17 Pentatomidae species were analyzed based on the concatenated matrix of cox1 and $r r n L$ using maximum likelihood (ML) on the IQ-TREE web server [40]. The matrix was partitioned by genes, and the best-fit partitioning schemes and substitution models were selected using the "Auto" option, resulting in TIM2+F+I+G4 for $\operatorname{cox} 1$ and GTR+F+I+G4 for $r r n L$. A 1000 ultrafast bootstrap approximation [41] was performed to evaluate the support values for branches. A phylogenetic hypothesis about the chosen species in each subfamily forming a monophyletic group was mainly adopted from Rider et al. [42] and treated as a constraint for tee search. Species from Largidae Amyot \& Serville, Rhopalidae Amyot \& Serville, and Reduviidae Latreille were selected as outgroups $[13,14,43]$. Ancestral character state reconstruction (ASR) was performed using the maximum parsimony method in Mesquite 3.51 [44]. Information on the morphological characteristics used for ASR was obtained from the present study and previous publications, summarized and coded in Table S11.

\section{Results and Discussion}

\subsection{Conserved Morphology and Sensilla Type of Antenna in Stink Bugs}

Insect antennae carry distinct types of olfactory sensilla that play various biological functions, such as orientation, foraging, and inter/intraspecific communication [28,39,40]. We found that antennal morphology and sensillum type are similar among the species of stink bugs we examined (Figures 1 and 2). The antennae of all 17 Pentatomidae are a pair of long and flexible sensory appendages, ventrolaterally located on the head, consisting of five segments: a proximal scape, a subdivided pedicel forming a basal segment and a distal segment, a basiflagellomere, and a distiflagellomere [11,12]. All of the segments are approximately cylindrical except the apex of distiflagellomere abruptly narrowed. We found four types of sensilla, namely sensilla chaetica, sensilla trichodea, sensilla basiconica, and sensilla coeloconica (Figures 2-4) [27,29]. They showed a conspicuous density gradient with the sensillum number increasing from antennal scape to distiflagellomere. In the six 
species examined in present study, C. divaricata and S. lurida have their antennal sensilla primarily located on the distiflagellomere, while the rest of species have most of their sensilla located on basi- and distiflagellomeres. The length, basal diameter, and distribution of these sensilla of the six species are provided in Tables S4-S9. The average density of basiconica sensilla on antennal distiflagellomere is summarized in Table S10.

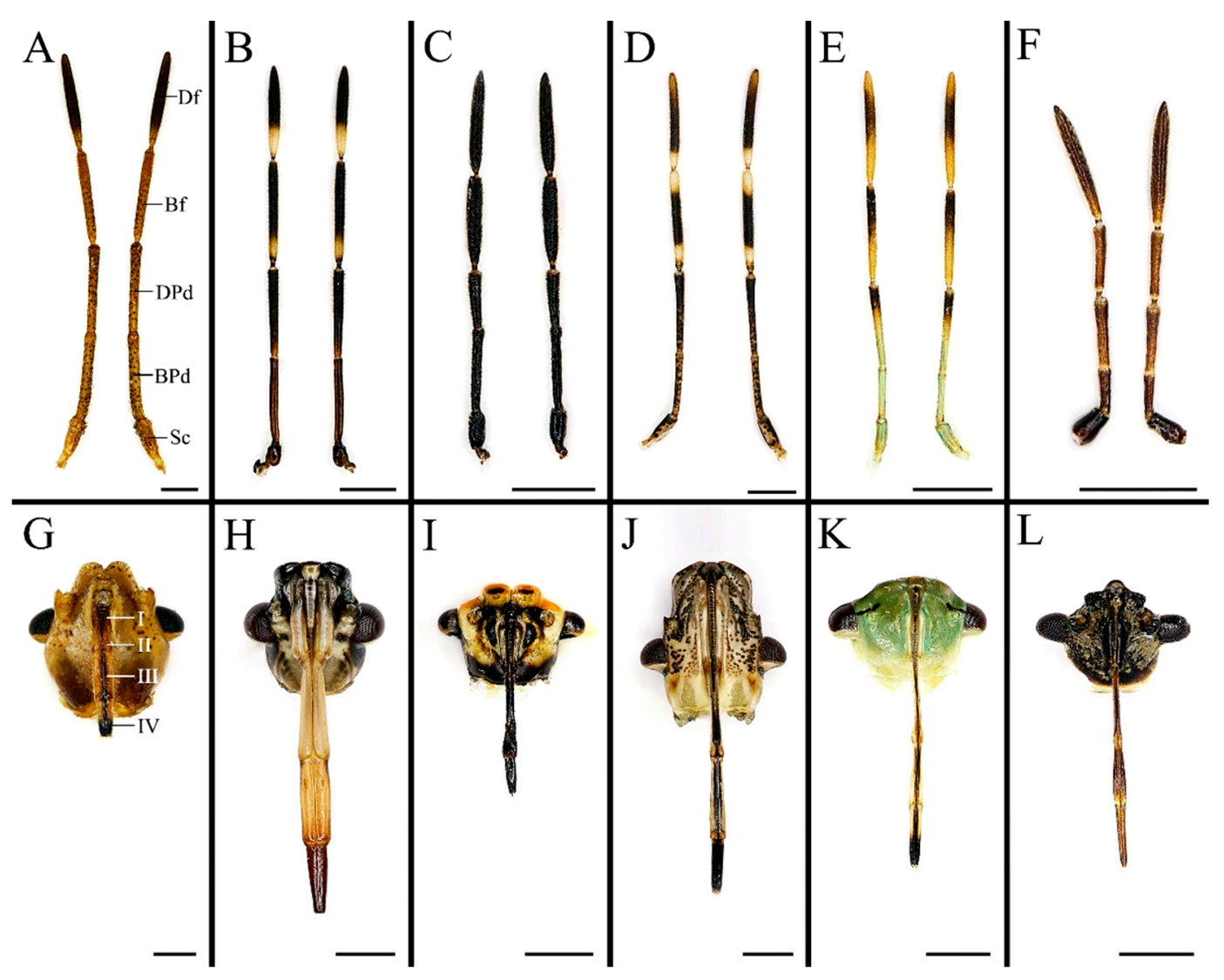

Figure 1. Antennae and labia of six pentatomid species examined in present study. (A,G) Cressona divaricata, (B,H) Eocanthecona furcellata, (C,I) Eurydema dominulus, (D,J) Halyomorpha halys, $(\mathbf{E}, \mathbf{K})$ Plautia crossota, and $(\mathbf{F}, \mathbf{L})$ Scotinophara lurida. Scale bars: (A-L) $1 \mathrm{~mm}$. Abbreviations: Bf, basiflagellomere; BPd, basal pedicel; Df, distiflagellomere; DPd, distal pedicel; and Sc, scape.

Antennal sensilla chaetica ( $\mathrm{AnCh}$ ) are stiff and strong, with deep grooves and welldeveloped sockets, representing one of the two dominant antennal sensillum types in stink bugs (Figures 2 and 3) [11,29]. Two subtypes of $\mathrm{Ch}$ can be distinguished among all of the sampled species. Antennal sensilla chaetica I (AnCh I) are sharp tipped, located on all of the five antennal segments in the six examined pentatomid species (Figures 2 and 3A,B,D). Antennal sensilla chaetica II (AnCh II) possess spoon shaped tips and are only detected on antennal scape and basal pedicel in Eo. furcellata (Figure 3C).

Antennal sensilla trichodea (AnTr) are slender and hair-like structures with tapered tips, acting as the other dominant type of antennal sensilla in pentatomids (Figures 2 and 3) [11,29]. Two subtypes of $\operatorname{Tr}$ can be distinguished. Antennal sensilla trichodea I (AnTr I) are longer and broader, possessing more distinct minute wall-pores (Figure 3E) than antennal sensilla trichodea II (AnTr II). In Eo. furcellata and Eu. dominulus, the bases of AnTr I are circled by evident pores (Figure 3E,F), while the bases of AnTr I are smooth and poreless in the other four species (Figure 3D,G-I). Antennal sensilla trichodea I and II are variously distributed in different species. In the six examined species, they are widely spread from the basal part of the pedicel to the distal end of distiflagellomere in H. halys. In Eo. furcellata and P. crossota, these organs can be found mainly on the distal subdivision of the pedicel to 
distiflagellomere. In C. divaricata, Eu. dominulus, and S. lurida, AnTr I and II are mostly distributed on the basiflagellomere and distiflagellomere.
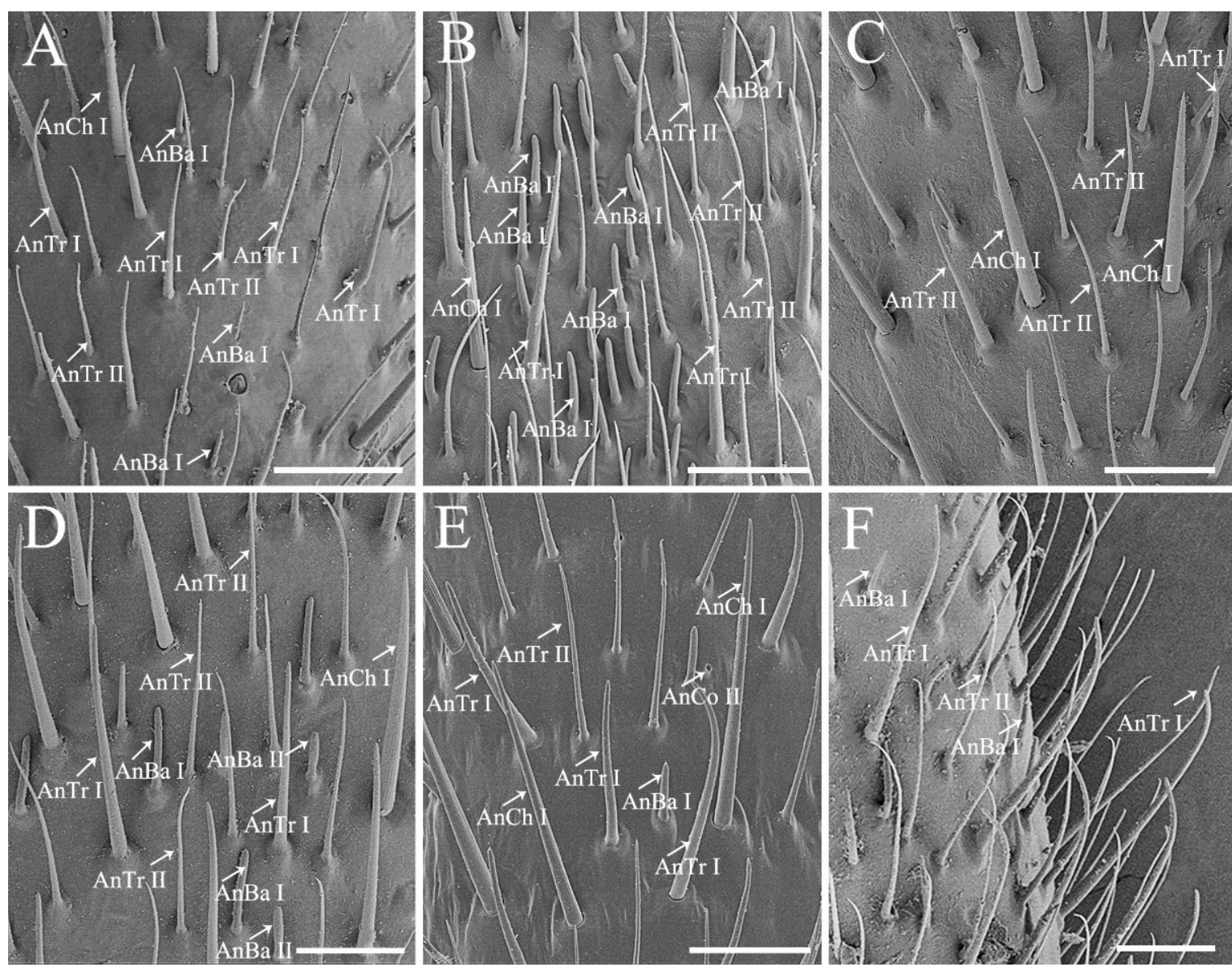

Figure 2. Dorsal view of the antennal distiflagellomere of the six pentatomid species, showing the distribution of antennal sensilla chaetica, sensilla trichodea, and sensilla basiconica. (A) Cressona divaricata, (B) Eocanthecona furcellata, (C) Eurydema dominulus, (D) Halyomorpha halys, (E) Plautia crossota, and (F) Scotinophara lurida. Scale bars: (A) $50 \mu \mathrm{m}$; (B-F) $25 \mu \mathrm{m}$. Abbreviations: AnBa I-II, antennal sensilla basiconica I-II; AnCh I, antennal sensilla chaetica I; AnTr I-II, antennal sensilla trichodea I-II; and AnCo II, antennal sensilla coeloconica II.

Antennal sensilla basiconica (AnBa) are peg-shaped. Two subtypes of Ba can be distinguished. Antennal sensilla basiconica I (AnBa I) and II (AnBa II) have abruptly blunt tips and straight longitudinal grooves exceeding half length of the sensilla (Figures 2 and $4 \mathrm{~A}-\mathrm{H}$ ). Antennal sensilla basiconica I are long and narrow, and AnBa II are short and broad. Both of them are located from the distal subdivision of antennal pedicel to distiflagellomere in Eo. furcellata, $H$. halys, and P. crossota but are mainly distributed on the two flagellomeres in C. divaricata, Eu. dominulus, and S. lurida. Sensilla basiconica are shorter in length and fewer in number than sensilla trichodea. Notably, a much higher density of sensilla basiconica is observed on distiflagellomere in predatory Eo. furcellata than in the phytophagous stink bugs (Figure 2; Tables 1 and S10). Antennal sensillum basiconica is the predominant sensillum type responsible for food odor reception for insects [45,46], and hence, the increased number of AnBa in predators might be associated with prey orientation and selection. 

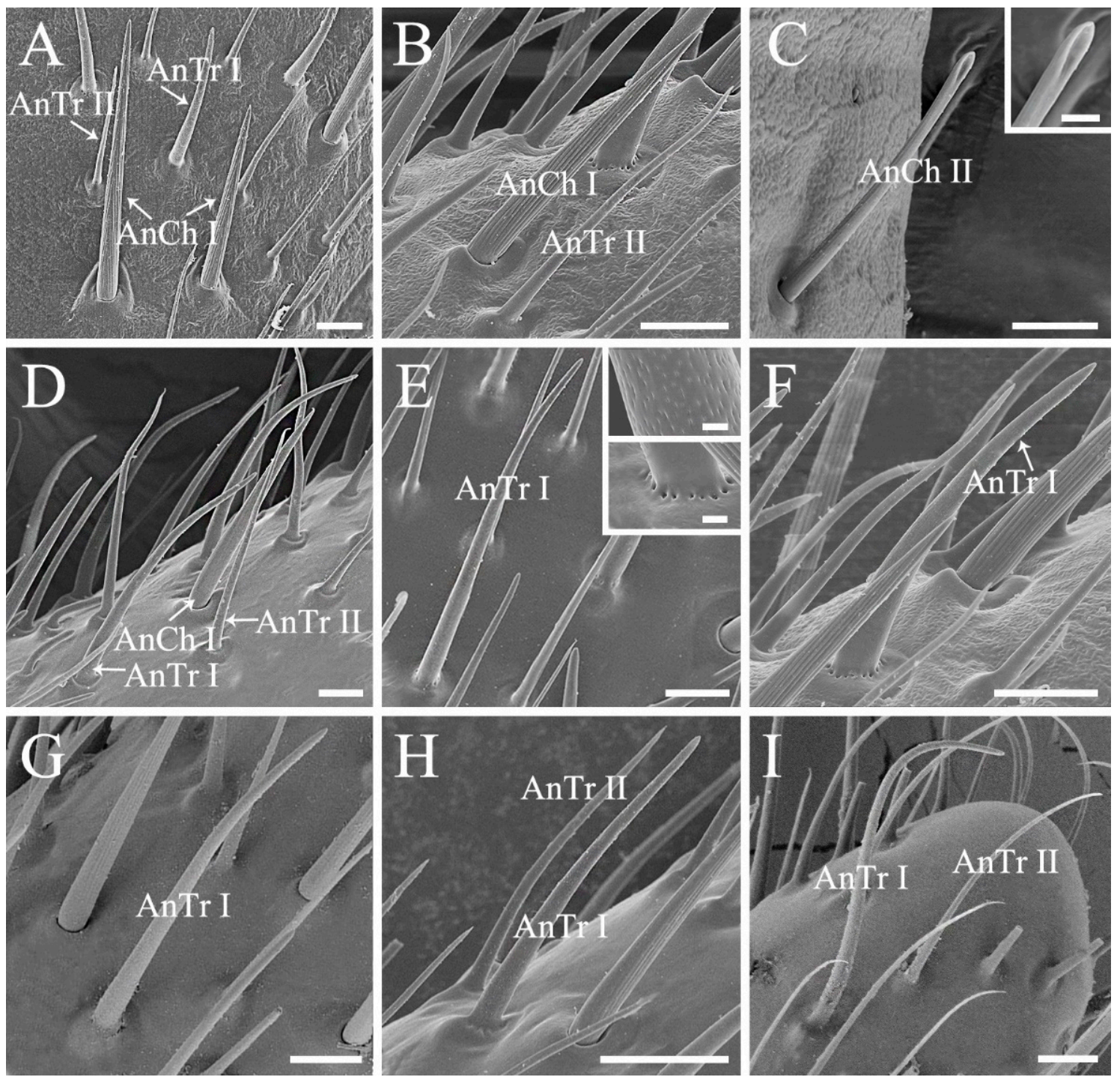

Figure 3. Antennal sensilla chaetica and sensilla trichodea of the six pentatomid species. (A,B,F) Eurydema dominulus; (C,E) Eocanthecona furcellata, showing the spoon shaped apex of Ch II in (C); (D) Cressona divaricata; (G) Halyomorpha halys; (H) Plautia crossota; and (I) Scotinophara lurida. Scale bars: (A-G,I) $10 \mu \mathrm{m},(\mathbf{C}) 2.5 \mu \mathrm{m}$, and (E) $0.5 \mu \mathrm{m}$; (H) $15 \mu \mathrm{m}$. Abbreviations: AnCh I-II, antennal sensilla chaetica I-II; AnTr I-II, antennal sensilla trichodea I-II.

Antennal sensilla coeloconica (AnCo) are cone-shaped and situated in cavities (Figure 4I-L). They are smaller and sparser than other types of sensilla. This type of sensilla is only found on the antennae of Eo. furcellata, $H$. halys, P. crossota, and S. lurida but absent on the other examined pentatomid species. Two subtypes of Co can be distinguished. Antennal sensilla coeloconica I (AnCo I) are larger in size, with the tips slightly elevated above the antennal surface and found in Eo. furcellata, H. halys, and P. crossota (Figure 4I-K); AnCo II are sunken deeply, with the tips below the surface and observed in Eo. furcellata, P. crossota, and S. lurida (Figure $4 \mathrm{I}, \mathrm{K}, \mathrm{L}$ ).

Antenna and its sensilla of insects are various in shape and structure, which are suggested to be shaped by adaptive evolution to detect certain odor molecules [35,45,47]. In the present study, we found that the general antennal morphology and sensillum types are conserved in stink bugs (Table 1), which reflects constraints imposed by phylogenetic relationships on basic architecture of antenna. Further study involved with molecular mechanisms of olfactory detection in Pentatomidae is in demand to understand antennal sensilla construction and function across stink bugs with varied feeding habits. 

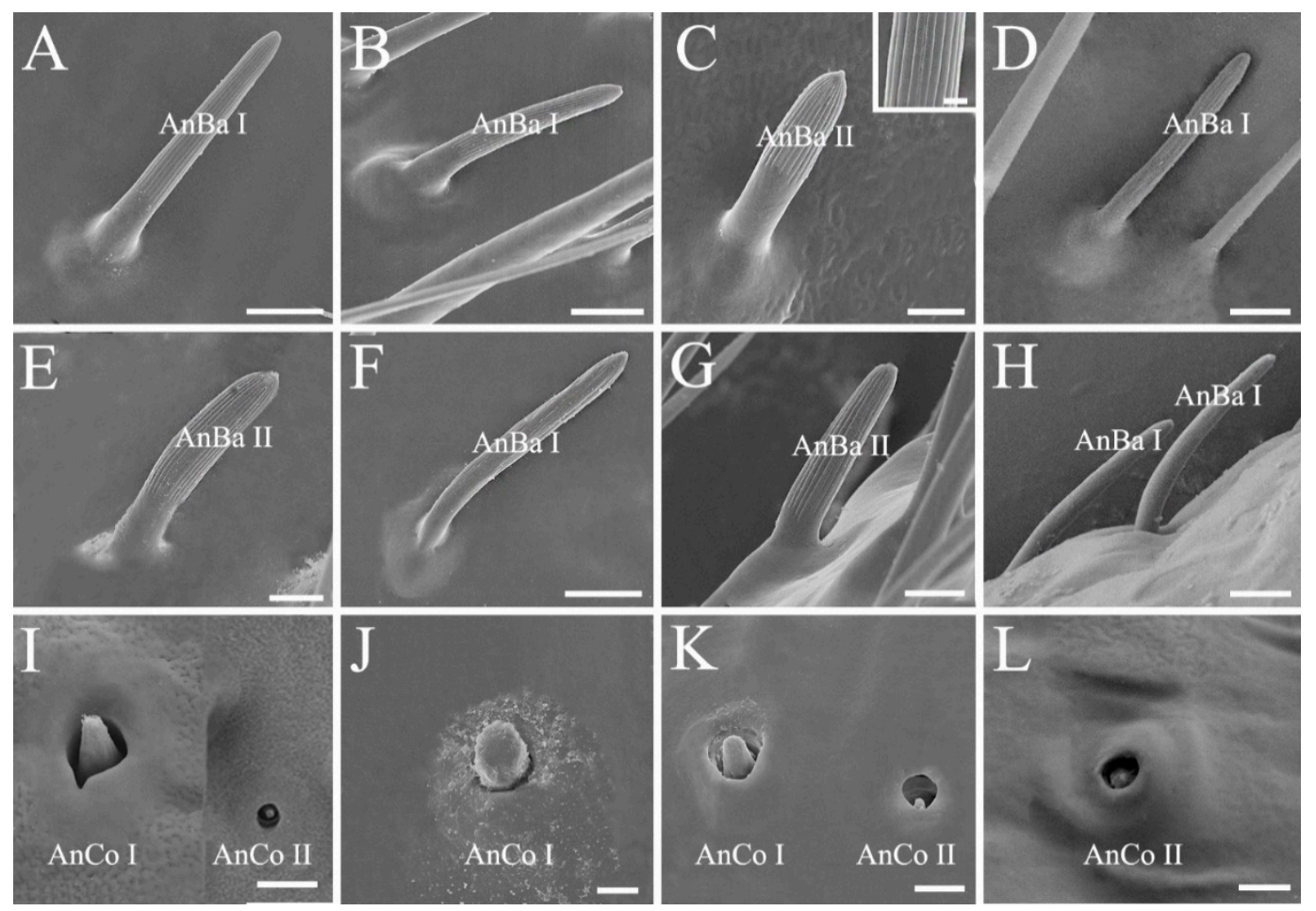

Figure 4. Antennal sensilla basiconica and sensilla coeloconica of the six pentatomid species. (A) Cressona divaricata; (B,I) Eocanthecona furcellata; (C) Eurydema dominulus, with grooves shown in the ox; (D,E,J) Halyomorpha halys; (F,G,K) Plautia crossota; and (H,L) Scotinophara lurida. Scale bars: $(\mathbf{A}, \mathbf{B}, \mathbf{D}, \mathbf{F}, \mathbf{H}) 5 \mu \mathrm{m},(\mathbf{C}, \mathbf{E}, \mathbf{G}, \mathbf{I}-\mathbf{L}) 2.5 \mu \mathrm{m}$, and (C) $0.5 \mu \mathrm{m}$. Abbreviations: AnBa I-II, antennal sensilla basiconica I-II; AnCo I-II, antennal sensilla coeloconica I-II.

Table 1. Morphological similarity and disparity of antennae and labia between phytophagous and predatory stink bugs.

\begin{tabular}{|c|c|c|}
\hline Morphological Characters & Similarity & Disparity \\
\hline Antennal morphology & $\begin{array}{c}\text { Five segments, including a } \\
\text { proximal scape, a subdivided } \\
\text { pedicel forming two segments, a basiflagellomere, and a } \\
\text { distiflagellomere }\end{array}$ & N.A. \\
\hline $\begin{array}{l}\text { Antennal sensilla type and } \\
\text { arrangement }\end{array}$ & $\begin{array}{c}\text { Mainly four types, antennal } \\
\text { sensilla chaetica, sensilla trichodea, sensilla basiconica, } \\
\text { and sensilla } \\
\text { coeloconica }\end{array}$ & $\begin{array}{c}\text { A higher density of sensilla basiconica is observed on } \\
\text { distiflagellomere in predatory Eocanthecona furcellata } \\
\text { than in phytophagous species }\end{array}$ \\
\hline Labial morphology & $\begin{array}{l}\text { Tubular; straight; and segmented into four, namely labial } \\
\text { segment I to IV from base to distal end }\end{array}$ & $\begin{array}{c}\text { Slender in phytophagous species while stout in } \\
\text { predators }\end{array}$ \\
\hline $\begin{array}{l}\text { Labial sensilla complex and } \\
\text { arrangement }\end{array}$ & $\begin{array}{c}\text { Mainly two types, labial sensilla trichodea and sensilla } \\
\text { basiconica }\end{array}$ & $\begin{array}{l}\text { Labial sensillum basiconica is the main type in } \\
\text { phytophagous species (except for Erthesina fullo), while } \\
\text { both sensillum trichodea and basiconica are the two } \\
\text { main types in predators. }\end{array}$ \\
\hline Labial cuticular projections & $\begin{array}{l}\text { Present in phytophagous and } \\
\text { predatory species }\end{array}$ & $\begin{array}{l}\text { Short and slightly branched in phytophagous species, } \\
\text { while long and multi-branched in predators }\end{array}$ \\
\hline Mandibular stylet shape & $\begin{array}{l}\text { With scale-like patterns, several central teeth, and lateral } \\
\text { teeth; and the central teeth are flattened, rounded, and } \\
\text { broad in phytophagous and predatory species }\end{array}$ & $\begin{array}{c}\text { aligned in phytophagous } \\
\text { species, while predators possess elongated and } \\
\text { hook-like lateral teeth irregularly arranged on the } \\
\text { mandible }\end{array}$ \\
\hline Maxillary stylet shape & $\begin{array}{l}\text { Left-right asymmetrical, with one stylet narrower than } \\
\text { the other on the distal end }\end{array}$ & $\begin{array}{l}\text { With short and sharp tipped barbs exclusively on the } \\
\text { maxillae of predatory species }\end{array}$ \\
\hline
\end{tabular}

\subsection{Ultrastructural Variations of the Labia between Species with Different Feeding Habits}

Labium of the sampled pentatomids is tubular, straight, and segmented by four, slender in plant feeders while stout in predators (Figure 1). A pair of the sensilla complex was laterally arranged on the labial apex, consisting of sensilla trichodea and sensilla 
basiconica (Figures 5 and 6; Table 1) [29,48]. The length and basal diameter of the labial sensilla detected in the examined six species are provided in Tables S4-S9.
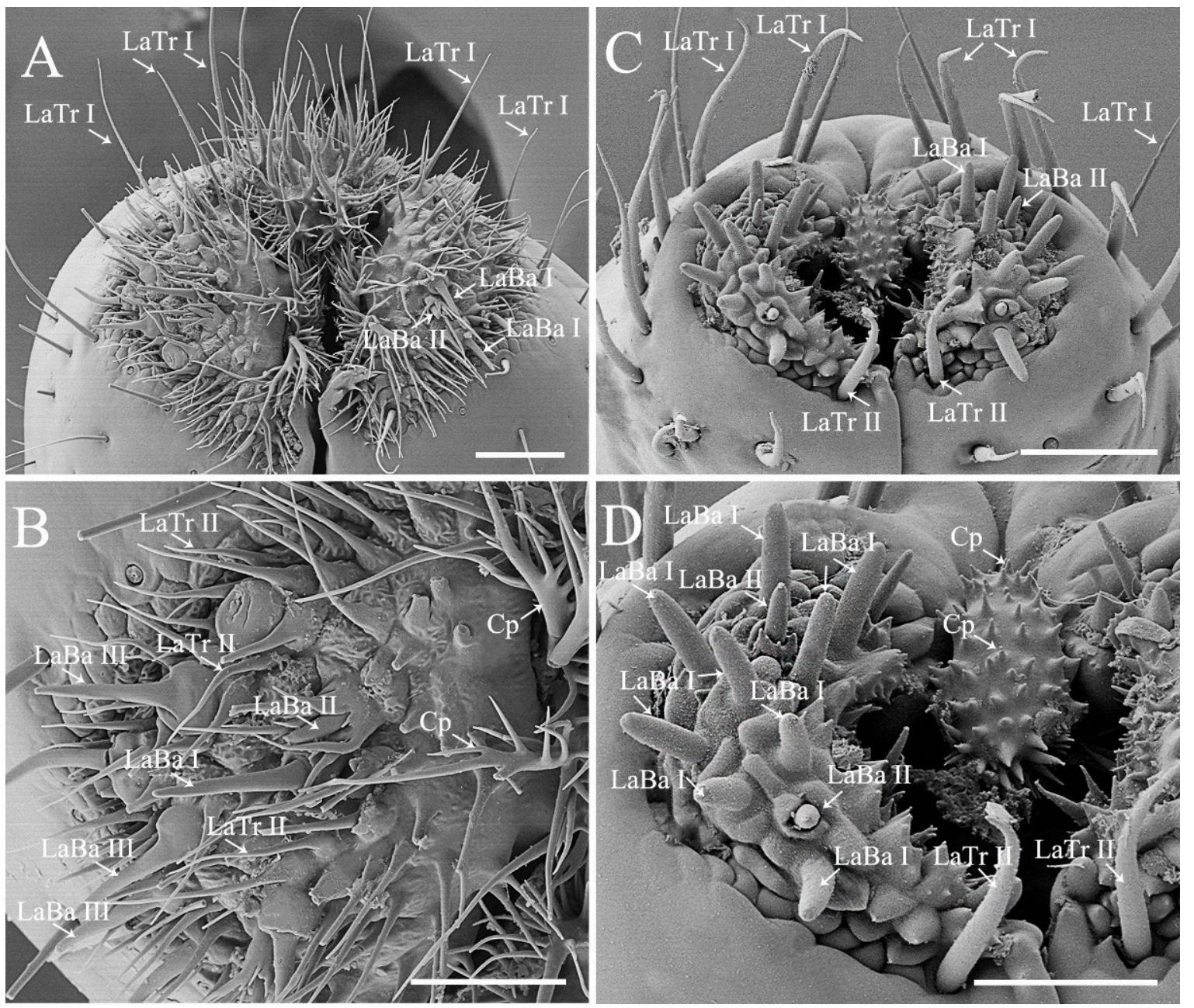

Figure 5. Labial apex of Eocanthecona furcellata (A,B) and Eurydema dominulus (C,D), showing labial sensilla and cuticular projections. Scale bars: (A,C) $30 \mu \mathrm{m}$; (B,D) $20 \mu \mathrm{m}$. Abbreviations: Cp, cuticular projection; LaBa III-V, labial sensilla basiconica III-V; and LaTr I-II, labial sensilla trichodea I-II.

Labial sensilla trichodea (LaTr) are long, slender, and sharp tipped. Two subtypes of LaTr can be distinguished by size and distribution. Labial sensilla trichodea I ( $\mathrm{LaTr}$ I) are long and marginally situated on the labial apex, while LaTr II are short and located in the labial sensilla complex (Figures 5 and 6; Tables S5-S8).

Labial sensilla basiconica ( $\mathrm{LaBa}$ ) are peg-shaped. Three subtypes of Ba can be distinguished. Labial sensilla basiconica I (LaBa I), II (LaBa II), and III (LaBa III) have smooth walls, with LaBa I possessing rounded tips and common bases (Figures 5C,D and 6). Labial sensilla basiconica II are morphologically similar to LaBa I, with the bases surrounded by inflexible sockets (Figures 5 and 6). Labial sensilla basiconica III are only detected in Eo. furcellata and some other Asopinae species [4,30]; they have gradually tapered tips and swollen bases (Figure 5A,B) and possibly play an important role in prey detection and orientation. 

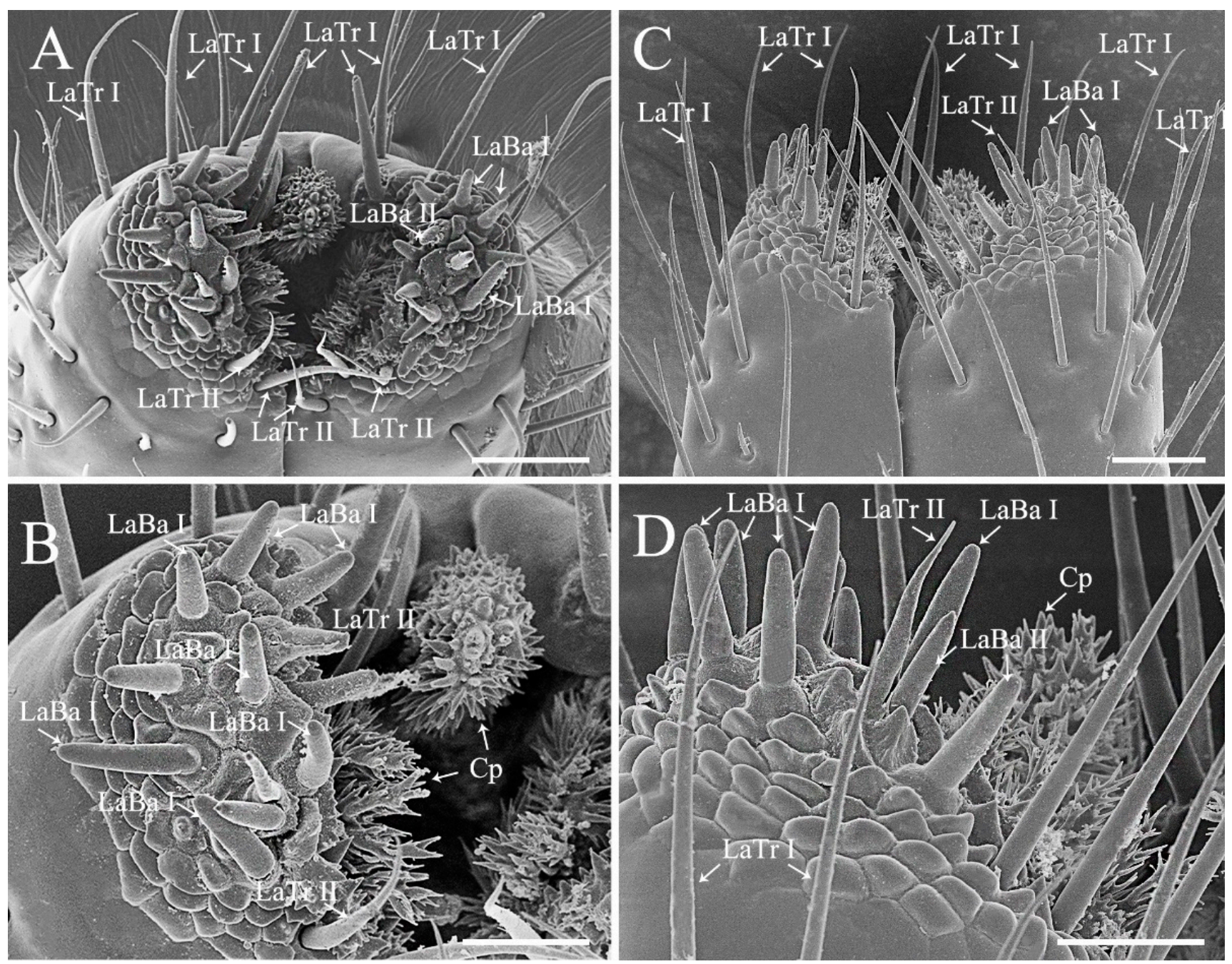

Figure 6. Labial apex of Halyomorpha halys (A,B) and Plautia crossota (C,D), showing labial sensilla and cuticular projections. Scale bars: (A,C) $25 \mu \mathrm{m}$; (B,D) $15 \mu \mathrm{m}$. Abbreviations: Cp, cuticular projection; LaBa I-II, labial sensilla basiconica I-II; and LaTr I-II, labial sensilla trichodea I-II.

Labial sensilla of heteropterans are crucial in responding to olfactory and gustatory signals, and excision of the labial apex strongly decreases the ability of prey orientation and capture efficiency [49]. In the present study, we found that the type and arrangement of labial sensilla seem to be differentiated between phytophagous and predatory species. Sensilla basiconica are the predominant type on the labial sensilla complex of plant feeding species, with sensilla trichodea singly scattered (Figures 5C,D and 6) [4,12]. Interestingly, similar sensilla type and arrangement have been reported in many other plant feeders in Pentatomomorpha (e.g., chinch bugs, plant bugs, and lace bugs) [50-52], which implies the importance of labial sensilla on interacting with host plants. Species Erthesina fullo (Thunberg, 1783) [53] is an interesting exception, which is a phytophagous species with numerous sensilla trichodea clustered on the labial sensilla complex [48]. In predaceous stink bugs, sensilla trichodea and basiconica are the two primary types on the labial sensilla complex (Figure 5A,B) [30]. They are highly morphologically similar with the sensilla found in phytophagous stink bugs but are much larger in size than the same type of labial sensilla detected in typical predatory true bugs (e.g., assassin bugs and water striders) [7,54]. This morphological resemblance between predaceous and plant feeding stink bugs indicates the phylogenetic constraints on shaping labial sensilla in true bugs.

Moreover, the shape of labial cuticular projections varies greatly across pentatomid species with different feeding habits. They are short and slightly branched in plant feeders 
(Figures 5C,D and 6A-D) but long and multi-branched in predators (Figure 5A,B) $[4,29,30,49]$. Although various function speculations of cuticular projections have been proposed (e.g., hygroreception, mechanoreception, and cleaning) $[4,29,49]$, their actual utility remains to be tested experimentally. In C. divaricata and S. lurida, the labial apex of all of the examined samples was covered with contaminants and difficult to be cleaned to show the shape of labial sensilla and cuticular projections; therefore, the labial apex of these two species is not illustrated in the present study.

\subsection{Modified Ultrastructure of Mandibles and Maxillae between Species with Different Feeding Habits}

Most of the stink bugs are phytophagous insects feeding mainly on seeds and immature fruits [55] in spite of twig or trunk feeding being reported in several species [56,57]. The subfamily Asopinae is an interesting exception, with all of the members being predators [17]. Feeding mechanism of pentatomids is composed of two main approaches, namely "salivary sheath" and "lacerate-and-flush" feeding, which is utilized by plant feeding and predaceous species, respectively. A sheath is formed by solidified gel saliva, surrounded the stylets to facilitate tissue penetration of the plant feeders. The predators use stylets to lacerate prey tissue to assist feeding [4,5,58,59]. Mandibles and maxillae (Figures 7 and 8) are the principal parts of the feeding structures in Heteroptera [1,5]. In this study, we found significant morphological variations in mandibular teeth between species with distinct diet types. The stylet bundle of pentatomid species is composed of a pair of mandibles and maxillae (Figures 7 and 8). They are long, thin and slender, bearing a strong inward curvature in the distal part in Eo. furcellata (Figures 7B and 8A,B) and some other predatory stink bugs $[9,30]$. Mandibles laterally surround the maxillae, forming tubular concentric stylets completely enclosed by labium posterior-ventrally. The mandibular stylet was distally ornamented with scale-like patterns, and several central and lateral teeth. The central teeth are flattened, rounded, and broad, singly arrayed in all 17 species (Table 1) $[4,9,30,48]$. The lateral teeth are distinct in shape and arranged between phytophagous and predatory species. They tend to be short, blunted, approximately triangular, and symmetrically aligned in pairs in plant feeders (Figure 7A,C-F) $[9,48]$, while in predatory species, they are sharp, elongated, hook-like, and irregularly arranged in predatory species (Figure 7B; Table 1) [4,30]. Additionally, the number of mandibular teeth varies among plant feeding species with different diet breaths. At least two central teeth and two pairs of lateral teeth are found in polyphagous herbivores (Figure 7C-F) $[4,9,48]$, whereas single central tooth and no lateral tooth is found in the oligophagous $C$. divaricata (Figure 7A; Table S3). Future tests including more species with narrowed diet breath will help to better illustrate the association between tooth number and diet breath.

Maxillary stylets of the examined species are left-right asymmetrical, with one stylet narrower than the other on the distal end (Figure 8). This is consistent with previous descriptions on other stink bugs [4]. Maxillary stylets are interlocked, forming a food canal and a salivary canal, a typical shared characteristic of heteropterans [2,4]. A series of short and sharp tipped barbs are exclusively present on the food canal of predatory Eo. furcellata (Figures 8A and 9), which is consistent with the observations from several other Asopinae species (Table 1) $[4,30]$. As a result, we suggest that ultrastructures from mandibular and maxillary stylets are the key characteristics associated with shift in feeding habits in stink bugs. 

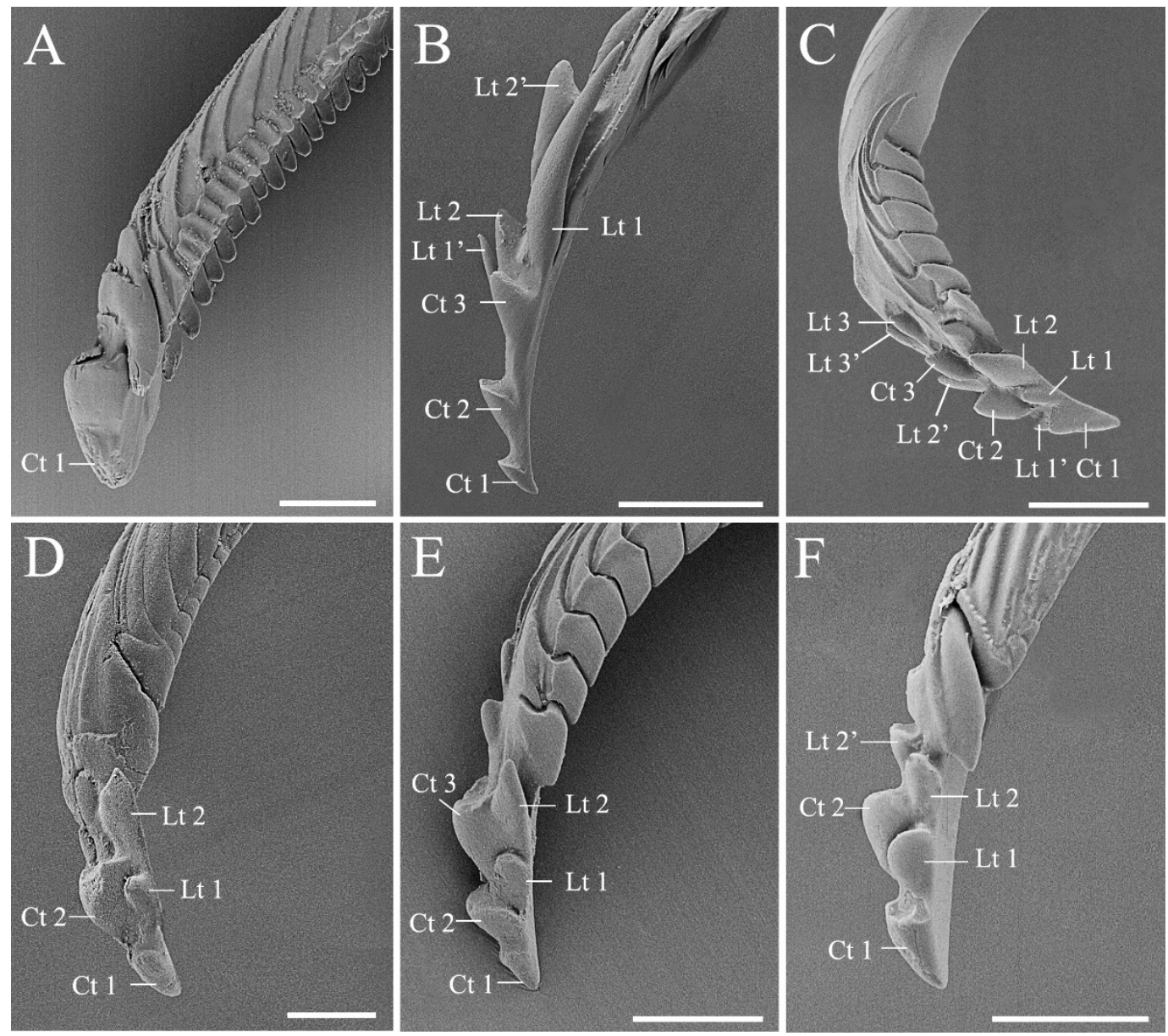

Figure 7. Mandibular stylet of the six pentatomid species. (A) Cressona divaricata, (B) Eocanthecona furcellata, (C) Eurydema dominulus, (D) Halyomorpha halys, (E) Plautia crossota, and (F) Scotinophara lurida. Scale bars: (A-E) $25 \mu \mathrm{m} ;(\mathbf{F}) 15 \mu \mathrm{m}$. Abbreviations: Ct, central teeth; Lt, lateral teeth.

\subsection{Ancestral States and Morphological Adaptations of Stink Bug Stylets}

To trace the ancestral shape and state transformation of mandibular and maxillary characteristics in stink bugs, ancestral state reconstructions were conducted based on the single fully resolved topology resulting from the phylogenetic analysis (Figure 9). Two dominant types of stylet bundle were classified, with the herbivore type characterized as mandible blunt-toothed and maxilla smooth, possessed by the ancestors in Pentatomidae. In Asopinae, the shape of stylet bundle was modified into the carnivore type, characterized as mandibles with sharp or even hook-like teeth and maxillae with sharp barbs, which might be an adaptation to their carnivorous feeding habit evolved independently (Figures 9 and S1). The mandibles of true bugs are often apically ornamented with various shaped teeth to facilitate penetration and anchoring of food [4,60]. It has been observed that the predatory stink bugs are capable of holding intensively struggling preys during predation [61] (e.g., personal observations of Eo. furcellata predating on fourth instar larvae of Asian corn borer); therefore, the sharp and hooked mandibular teeth present in the asopines might assist in the immobilization of living preys. Maxillary barbs were also documented in many other predaceous families and infraorders in Heteroptera (e.g., Reduviidae in Cimicomorpha; Hydrometridae in Gerromophora; and Belostomatidae, Nepidae, and Notonectidae in Nepomorpha) $[4,30]$. It is hypothesized that these barbs may serve to filter and triturate large-sized substrates for further digestion and absorption [4,5]. Considering that the ancestors of predatory stink bugs originated from plant feeding species in a largely phytophagous infraorder Pentatomomorpha $[13,14,43]$, the presence of sharp mandibular 
teeth and maxillary barbs is likely to be a key innovation associated with transition from herbivorous to carnivorous feeding habit in Pentatomidae.
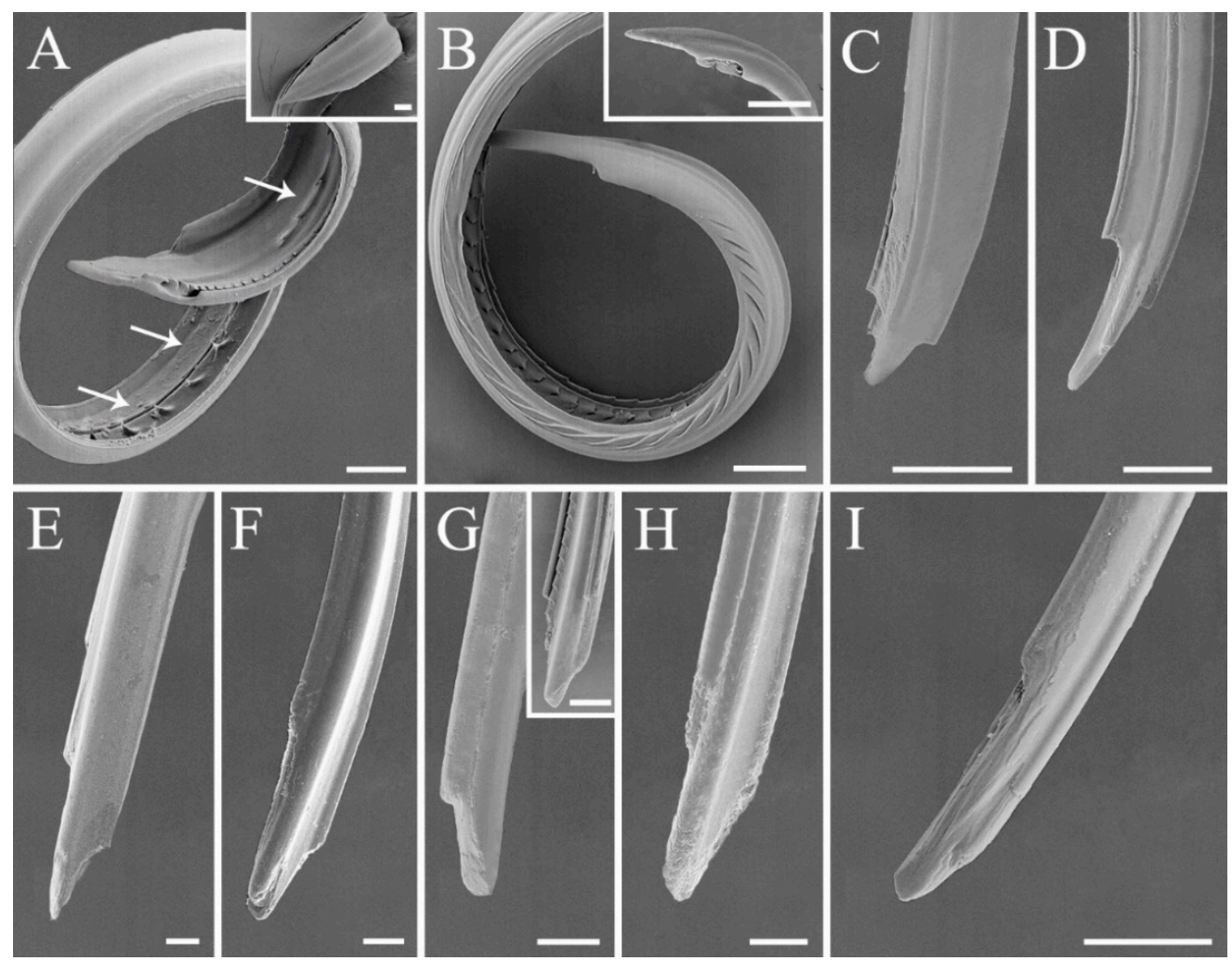

Figure 8. Maxillary stylets of the six pentatomid species. (A,B) Eocanthecona furcellata, with the external surface shown in the boxes and the arrows indicating the barbs; (C,D) Eurydema dominulus; (E,F) Halyomorpha halys; (G,H) Plautia crossota, with the internal surface shown in (G); (I) Scotinophara lurida. Scale bars: (A-D) $25 \mu \mathrm{m},(\mathbf{A}, \mathbf{B}) 20 \mu \mathrm{m},(\mathbf{E}, \mathbf{F}) 20 \mu \mathrm{m},(\mathbf{G}-\mathbf{I})$ $15 \mu \mathrm{m}$, and (G) $25 \mu \mathrm{m}$.

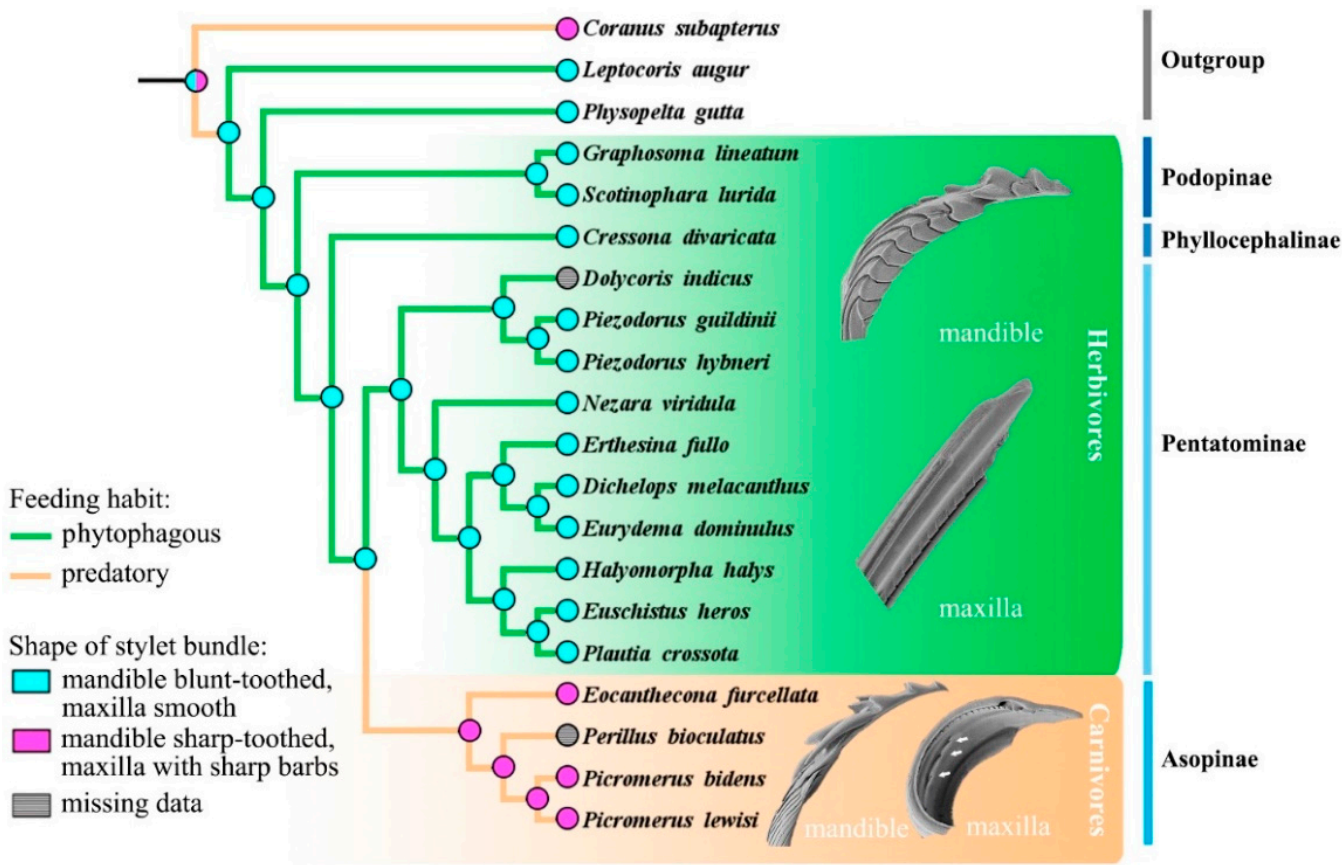

Figure 9. Ancestral state reconstruction of the shapes of mandibles and maxillae in Pentatomidae based on parsimony. The cladogram used for reconstruction was the single tree obtained based on the cox 1 and $r r n L$ genes analyzed using the maximum likelihood method. 


\section{Conclusions}

Overall, our study demonstrates that antennal and mouthpart ultrastructures vary remarkably across stink bug species with distinct feeding habits and, thus, might be key morphological characteristics driving feeding habit evolution in these insects. The types and arrangements of antennal and labial sensilla are different between predators and plant feeders, implying their crucial function in food orientation and selection. Particularly, we found that the mandibles are fringed with long and hook-like teeth and that the maxillae are ornamented with sharp barbs exclusively in predators. These ultrastructural modifications indicate their tight association with the shift in feeding habit from phytophagy to predation. Comparative morphological analysis involving a larger taxa sampling, together with the exploration of adaptive significance of these structural variations would shed light on how morphological evolution drives the adaptive diversification of feeding habits in these ecologically and economically important insect group.

Supplementary Materials: The following are available online at https://www.mdpi.com/article/10 $.3390 /$ biology10111161/s1, Figure S1, Ancestral state reconstruction of the shape of mandible (left) and maxilla (right) in Pentatomidae based on parsimony; Table S1, Genes accession numbers of cox1 and $r r n L$ for the species sampled in the present study; Table S2, Taxonomic and collected information on the stink bug species sampled in the present study; Table S3, Host plant information on the stink bug species sampled in the present study; Tables S4-S9, Morphometric data of labial and antennal sensilla of the six stink bug species examined in this study; Table S10, Average density of basiconica sensilla on antennal distiflagellomere of the stink bug species examined in the present study; Table S11, Morphological characteristics used for ancestral state reconstruction.

Author Contributions: Conceptualization, X.L., H.L. and W.C.; methodology, X.L.; validation, X.L., L.T., H.L. and W.C.; formal analysis, X.L.; investigation, X.L. and L.T.; resources, H.L. and W.C; data curation, X.L.; writing —original draft preparation, X.L.; writing—review and editing, X.L., L.T., H.L. and W.C.; visualization, X.L.; supervision, H.L. and W.C.; project administration, W.C.; funding acquisition, H.L. and W.C. All authors have read and agreed to the published version of the manuscript.

Funding: This study was partly supported by the grant from National Natural Science Foundation of China (no. 31730086), Guizhou Tobacco Company of China National Tobacco Corporation (Science and Technology Major Project no. 201940), and Expert Workstation in Zhaotong, Yunnan (no. 2019ZTYX03).

Institutional Review Board Statement: Not applicable.

Informed Consent Statement: Not applicable.

Data Availability Statement: The data generated in this study are provided here or in the Supplementary Materials, and they are also available upon request from the corresponding author.

Acknowledgments: We thank Xinli Wei and Chunli Li (Institute of Microbiology, Chinese Academy of Sciences) for their help in using the scanning electronic microscope.

Conflicts of Interest: The authors declare no conflict of interest.

\section{References}

1. Henry, T.J. Biodiversity of Heteroptera. In Insect Biodiversity: Science and Society; Foottit, R.G., Adler, P.H., Eds.; John Wiley \& Sons Ltd.: Hoboken, NJ, USA, 2009; Volume 1, pp. 223-263.

2. Schuh, R.T.; Weirauch, C. The True Bugs of the World (Hemiptera: Heteroptera): Classification and Natural History, 2nd ed.; Siri Scientific Press: Manchester, UK, 2020; pp. 1-769.

3. Panizzi, A.R.; Grazia, J. True Bugs (Heteroptera) of the Neotropics; Springer: Dordrecht, The Netherlands, 2015 ; pp. 1-901.

4. Cobben, R.H. Evolutionary Trends in Heteroptera. Part 2. Mouth Part Structures and Feeding Strategies. Mededlingen Landbouwhogeschool; H. Veeman \& Zonen B.V.: Wageningen, The Netherlands, 1978; pp. 1-407.

5. Cohen, A.C. Feeding adaptations of some predaceous Hemiptera. Ann. Entomol. Soc. Am. 1990, 83, 1215-1223. [CrossRef]

6. Krenn, H.W.; Aspöck, H. Form, function and evolution of the mouthparts of blood-feeding Arthropoda. Arthropod Struct. Dev. 2012, 41, 101-118. [CrossRef] [PubMed] 
7. Brożek, J.; Zettel, H. A comparison of the external morphology and functions of labial tip sensilla. Eur. J. Entomol. 2014, 111, 275-297. [CrossRef]

8. Swart, C.C.; Felgenhauer, B.E. Structure and function of the mouthparts and salivary gland complex of the giant waterbug, Belostoma lutarium (Stål) (Hemiptera: Belostomatidae). Ann. Entomol. Soc. Am. 2003, 96, 870-882. [CrossRef]

9. Depieri, R.A.; Panizzi, A.R. Rostrum length, mandible serration, and food and salivary canals areas of selected species of stink bugs (Heteroptera, Pentatomidae). Rev. Bras. Entomol. 2010, 54, 584-587. [CrossRef]

10. Wang, Y.; Brożek, J.; Dai, W. Morphological disparity of the mouthparts in polyphagous species of Largidae (Heteroptera: Pentatomomorpha: Pyrrhocoroidea) reveals feeding specialization. Insects 2020, 11, 145. [CrossRef]

11. Silva, C.C.A.; de Capdeville, G.; Moraes, M.C.B.; Falcão, R.; Solino, L.F.; Laumann, R.A.; Silva, J.P.; Borges, M. Morphology, distribution and abundance of antennal sensilla in three stink bug species (Hemiptera: Pentatomidae). Micron 2010, 41, 289-300. [CrossRef]

12. Ahmad, A.; Parveen, S.; Brożek, J.; Dey, D. Antennal sensilla of phytophagous and predatory pentatomids (Hemiptera: Pentatomidae): A comparative study of four genera. Zool. Anz. 2016, 261, 48-55. [CrossRef]

13. Li, H.; Leavengood, J.M.; Chapman, E.G.; Burkhardt, D.; Song, F.; Jiang, P.; Liu, J.; Zhou, X.; Cai, W. Mitochondrial phylogenomics of Hemiptera reveals adaptive innovations driving the diversification of true bugs. Proc. R. Soc. B Biol. Sci. 2017, $284,20171223$. [CrossRef]

14. Weirauch, C.; Schuh, R.T.; Cassis, G.; Wheeler, W.C. Revisiting habitat and lifestyle transitions in Heteroptera (Insecta: Hemiptera): Insights from a combined morphological and molecular phylogeny. Cladistics 2019, 35, 67-105. [CrossRef]

15. Weirauch, C.; Schuh, R.T. Systematics and evolution of heteroptera: 25 years of progress. Annu. Rev. Entomol. 2011, 56, 487-510. [CrossRef]

16. Roca-Cusachs, M.; Schwertner, C.F.; Kim, J.; Eger, J.; Grazia, J.; Jung, S. Opening Pandora's box: Molecular phylogeny of the stink bugs (Hemiptera: Heteroptera: Pentatomidae) reveals great incongruences in the current classification. Syst. Entomol. 2021. [CrossRef]

17. Panizzi, A.R.; McPherson, J.E.; James, D.G.; Javahery, M.; McPherson, M.R. Stink bugs (Pentatomidae). In Heteroptera of Economic Importance; Schaefer, W.C., Panizzi, A.R., Eds.; CRC Press: Boca Raton, FL, USA, 2000; pp. 421-474.

18. Stål, C. Öfversigt af Kongl. Vetenskaps-Akademiens Forhandlingar; P. A. Norstedt \& Söner: Stockholm, Sweden, 1855; Volume 12, p. 182.

19. Todd, J.W. Ecology and behavior of Nezara viridula. Annu. Rev. Entomol. 1989, 34, 273-292. [CrossRef]

20. Koch, R.L.; Pezzini, D.T.; Michel, A.P.; Hunt, T.E. Identification, biology, impacts, and management of stink bugs (Hemiptera: Heteroptera: Pentatomidae) of soybean and corn in the midwestern United States. J. Integr. Pest Manag. 2017, 8, 11. [CrossRef]

21. Powell, G. The biology and control of an emerging shield bug pest, Pentatoma rufipes (L.) (Hemiptera: Pentatomidae). Agric. For. Entomol. 2020, 22, 298-308. [CrossRef]

22. Leskey, T.C.; Nielsen, A.L. Impact of the invasive brown marmorated stink bug in north America and Europe: History, biology, ecology, and management. Annu. Rev. Entomol. 2018, 63, 599-618. [CrossRef] [PubMed]

23. Moore, L.; Tirello, P.; Scaccini, D.; Toews, M.D.; Duso, C.; Pozzebon, A. Characterizing damage potential of the brown marmorated stink bug in cherry orchards in Italy. Entomol. Gen. 2019, 39, 271-283. [CrossRef]

24. Wolff, J.F. Icones Cimicum Descriptionibus Illustratae; Palm: Erlangen, Germany, 1811; Volume 5, p. 182.

25. Roca-Cusachs, M.; Kim, J.; Park, J.; Jung, S. Taxonomic review of the predatory stink bugs of the Korean Peninsula (Heteroptera: Pentatomidae: Asopinae), with a key to the Korean species and a discussion of their usefulness as biological control agents. $J$. Asia Pac. Entomol. 2020, 23, 113-123. [CrossRef]

26. Schaefer, C.W.; Panizzi, A.R. Heteroptera of Economic Importance; CRC Press: Boca Raton, FL, USA, 2000 ; pp. 3-828.

27. Rani, P.U.; Madhavendra, S.S. Morphology and distribution of antennal sense organs and diversity of mouthpart structures in Odontopus nigricornis (Stål) and Nezara viridula L. (Hemiptera). Int. J. Insect Morphol. Embryol. 1995, 24, 119-132. [CrossRef]

28. Brézot, P.; Tauban, D.; Renou, M. Sense organs on the antennal flagellum of the green stink bug, Nezara viridula (L.) (Heteroptera: Pentatomidae): Sensillum types and numerical growth during the post-embryonic development. Int. J. Insect Morphol. Embryol. 1996, 25, 427-441. [CrossRef]

29. Parveen, S.; Ahmad, A.; Broek, J.; Ramamurthy, V.V. Morphological diversity of the labial sensilla of phytophagous and predatory Pentatomidae (Hemiptera: Heteroptera), with reference to their possible functions. Zootaxa 2015, 4039, 359-372. [CrossRef] [PubMed]

30. Wang, Y.; Brożek, J.; Dai, W. Comparative morphology of the mouthparts in three predatory stink bugs (Heteroptera: Asopinae) reveals feeding specialization of stylets and sensilla. Insects 2020, 11, 762. [CrossRef] [PubMed]

31. Zheng, L.Y.; Zou, H.G. Records of heteropterous insects on bamboo from Yunnan. Zool. Res. 1982, 3, 113-120.

32. Scopoli, J.A. Entomologia Carniolica Exhibens Insecta Carnioliae Indigena et Distributa in Ordines, Genera, Species, Varietatis. Methodo Linnaeana; Trattner: Vindobonae, Austria, 1763; p. 124.

33. Dallas, W.S. List of the Specimens of Hemipterous Insects in the Collection of the British Museum. Part I; Trustees of the British Museum: London, UK, 1851; pp. 1-368.

34. Burmeister, H. Rhyngota seu Hemiptera. In: Meyen, F.J.F Beiträge zur Zoologie, gesammelt auf einer Reise um die Erde, und W. Erichson's und H. Burmeister's Beschreibungen und Abbildungen der von Herrn Meyen auf dieser Reise gesammelten Insekten. Nov. Acta Acad. Caesareae Leopold.-Carol. Nat. Curiosorum 1834, 16, 285-308. 
35. Schneider, D. Insect antennae. Annu. Rev. Entomol. 1964, 9, 103-122. [CrossRef]

36. Simon, C.; Buckley, T.R.; Frati, F.; Stewart, J.B.; Beckenbach, A.T. Incorporating molecular evolution into phylogenetic analysis, and a new compilation of conserved polymerase chain reaction primers for animal mitochondrial DNA. Annu. Rev. Ecol. Evol. Syst. 2006, 37, 545-579. [CrossRef]

37. Li, H.; Liu, H.; Cao, L.; Shi, A.; Yang, H.; Cai, W. The complete mitochondrial genome of the damsel bug Alloeorhynchus bakeri (Hemiptera: Nabidae). Int. J. Biol. Sci. 2011, 8, 93-107. [CrossRef]

38. Kuraku, S.; Zmasek, C.M.; Nishimura, O.; Katoh, K. aLeaves facilitates on-demand exploration of metazoan gene family trees on MAFFT sequence alignment server with enhanced interactivity. Nucleic Acids Res. 2013, 41, W22-W28. [CrossRef]

39. Katoh, K.; Rozewicki, J.; Yamada, K.D. MAFFT online service: Multiple sequence alignment, interactive sequence choice and visualization. Brief. Bioinform. 2018, 20, 1160-1166. [CrossRef]

40. Trifinopoulos, J.; Nguyen, L.T.; von Haeseler, A.; Minh, B.Q. W-IQ-TREE: A fast online phylogenetic tool for maximum likelihood analysis. Nucleic Acids Res. 2016, 44, W232-W235. [CrossRef]

41. Minh, B.Q.; Nguyen, M.A.T.; Von Haeseler, A. Ultrafast approximation for phylogenetic bootstrap. Mol. Biol. Evol. 2013, 30, 1188-1195. [CrossRef]

42. Rider, D.A.; Schwertner, C.F.; Vilímová, J.; Rédei, D.; Kment, P.; Thomas, D.B. Higher systematics of the Pentatomoidea. In Invasive Stink Bugs and Related Species (Pentatomoidea); McPherson, J.E., Ed.; CRC Press: Boca Raton, FL, USA, 2018 ; pp. 25-202.

43. Liu, Y.; Li, H.; Song, F.; Zhao, Y.; Wilson, J.J.; Cai, W. Higher-level phylogeny and evolutionary history of Pentatomomorpha (Hemiptera: Heteroptera) inferred from mitochondrial genome sequences. Syst. Entomol. 2019, 44, 810-819. [CrossRef]

44. Maddison, W.P.; Maddison, D.R. Mesquite: A Modular System for Evolutionary Analysis. Version 3.51. 2018. Available online: http:/ / www.mesquiteproject.org (accessed on 1 December 2018).

45. Steinbrecht, R.A. Structure and function of insect olfactory sensilla. In Olfaction in Mosquito-Host Interactions; Bock, G., Cardew, G., Hildebrand, J., Eds.; Wiley: Chichester, UK, 1996; pp. 158-177.

46. Grabe, V.; Sachse, S. Fundamental principles of the olfactory code. Biosystems 2018, 164, 94-101. [CrossRef]

47. Hallem, E.A.; Dahanukar, A.; Carlson, J.R. Insect odor and taste receptors. Annu. Rev. Entomol. 2006, 51, 113-135. [CrossRef]

48. Wang, Y.; Dai, W. How does the intricate mouthpart apparatus coordinate for feeding in the hemimetabolous insect pest Erthesina fullo? Insects 2020, 11, 503. [CrossRef] [PubMed]

49. Usha Rani, P.; Wakamura, S. Host acceptance behaviour of a predatory pentatomid, Eocanthecona furcellata (Wolff) (Heteroptera: Pentatomidae) towards larvae of Spodoptera litura (Lepidoptera: Noctuidae). Int. J. Trop. Insect Sci. 1993, 14, 141-147. [CrossRef]

50. Wang, Y.; Li, L.; Dai, W. Fine morphology of the mouthparts in Cheilocapsus nigrescens (Hemiptera: Heteroptera: Miridae) reflects adaptation for phytophagous habits. Insects 2019, 10, 143. [CrossRef] [PubMed]

51. Wang, Y.; Brożek, J.; Dai, W. Sensory armature and stylets of the mouthparts of Stephanitis nashi (Hemiptera: Cimicomorpha: Tingidae), their morphology and function. Micron 2020, 132, 102840. [CrossRef]

52. Baker, G.T.; Xiong, C.; Ma, P.W.K. Labial tip sensilla of Blissus leucopterus leucopterus (Hemiptera: Blissidae): Ultrastructure and behavior. Insect Sci. 2008, 15, 271-275. [CrossRef]

53. Thunberg, C.P. Dissertatio Entomologica Novas Insectorum Species, Sistens, Cujus Partem Secundum; Edman: Upsaliae, Sweden, 1783; p. 42.

54. Brożek, J.; Chłond, D. Morphology, arrangement and classification of sensilla on the apical segment of labium in Peiratinae (Hemiptera: Heteroptera: Reduviidae). Zootaxa 2010, 2476, 39. [CrossRef]

55. Panizzi, A.R. Wild hosts of pentatomids: Ecological significance and role in their pest status on crops. Annu. Rev. Entomol. 1997, 42, 99-122. [CrossRef] [PubMed]

56. Scaccini, D.; Pozzebon, A. Invasive brown marmorated stink bug (Hemiptera: Pentatomidae) facilitates feeding of European wasps and ants (Hymenoptera: Vespidae, Formicidae) on plant exudates. Eur. J. Entomol. 2021, 118, 24-30. [CrossRef]

57. Martinson, H.M.; Raupp, M.J.; Shrewsbury, P.M. Invasive stink bug wounds trees, liberates sugars, and facilitates native Hymenoptera. Ann. Entomol. Soc. Am. 2013, 106, 47-52. [CrossRef]

58. Miles, P.W. The saliva of Hemiptera. Adv. Insect Physiol. 1972, 9, 183-255. [CrossRef]

59. Backus, E.A. Sensory systems and behaviours which mediate hemipteran plant-feeding: A taxonomic overview. J. Insect Physiol. 1988, 34, 151-165. [CrossRef]

60. Wang, Y.; Zhang, J.; Wang, W.; Brożek, J.; Dai, W. Unique fine morphology of mouthparts in Haematoloecha nigrorufa (Stål) (Hemiptera: Reduviidae) adapted to millipede feeding. Insects 2020, 11, 386. [CrossRef]

61. Lemos, W.P.; Zanuncio, J.C.; Serrão, J.E. Attack behavior of Podisus rostralis (Heteroptera: Pentatomidade) adults on caterpillars of Bombyx mori (Lepidoptera: Bombycidae). Braz. Arch. Biol. Technol. 2005, 48, 975-981. [CrossRef] 